A REVIEW OF HEAT/MASS BALANCES AND PRODUCT DATA

FOR PARTIAL OXIDATION OF CATTLE

FEEDLOT MANURE

William J. Huffman

Steven R. Beck

Brian L. Landeene

James E. Halligan

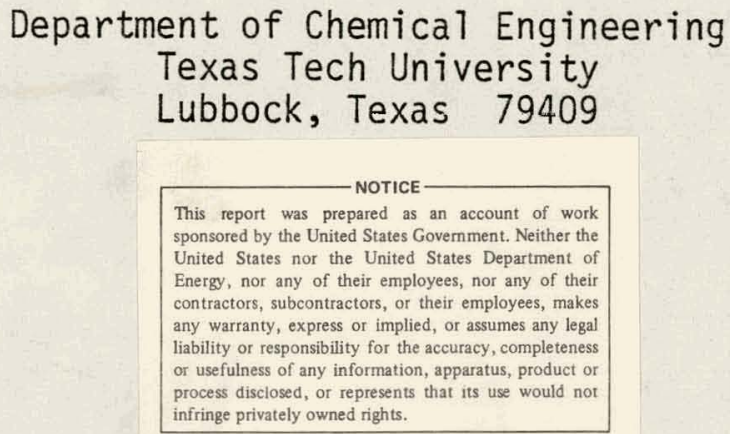

AIChE 84th National Meeting

Atlanta, Georgia

February 26 - March 1, 1978 


\section{DISCLAIMER}

This report was prepared as an account of work sponsored by an agency of the United States Government. Neither the United States Government nor any agency Thereof, nor any of their employees, makes any warranty, express or implied, or assumes any legal liability or responsibility for the accuracy, completeness, or usefulness of any information, apparatus, product, or process disclosed, or represents that its use would not infringe privately owned rights. Reference herein to any specific commercial product, process, or service by trade name, trademark, manufacturer, or otherwise does not necessarily constitute or imply its endorsement, recommendation, or favoring by the United States Government or any agency thereof. The views and opinions of authors expressed herein do not necessarily state or reflect those of the United States Government or any agency thereof. 


\section{DISCLAIMER}

Portions of this document may be illegible in electronic image products. Images are produced from the best available original document. 


\title{
A REVIEW OF HEAT/MASS BALANCES AND PRODUCT DATA \\ FOR PARTIAL OXIDATION OF CATTLE FEEDLOT MANURE
}

\author{
by \\ William J. Huffman ${ }^{\star}$, Steven R. Beck, Brian L. \\ Landeene**, James $E$. Halligan ${ }^{\star \star \star}$ \\ Department of Chemical Engineering \\ Texas Tech University \\ Lubbock, Texas 79409
AIChE 84th National Meeting
Atlanta, Georgia \\ February 26 - March 1, 1978
}

Thermochemical conversion of biomass offers an opportunity to increase the world's reserves of hydrocarbon resources $(1,2,3)$. Biomass can be defined as solar energy stored in the form of plant matter and residues that have some positive value as a chemical resource. This is in contrast to wastes which have a negative value, e.g. - one must pay to dispose of wastes. Biomass is a very desirable hydrocarbon resource because it is renewable and thus, in theory, should provide an inexhaustable supply. The major obstacle to the implementation of biomass technology is that the energy density of biomass is very low compared to fossil fuels as shown below. Projections for silvaculture are that 8 tons/acre-yr. of wood could be produced. If

Current Addresses

*Battelle Memorial Institute, Columbus, Ohio.

**Mobil Chemical Company, Beaumont, Texas.

$\star \star \star$ Dean of Engineering, University of Missouri-Rolla, Rolla, Missouri. 
one assumes that wood has a heating value of $6,000 \mathrm{BTU} / 1 \mathrm{~b}$, the energy density would be $92 \times 10^{6}$ BTU/acre.

$$
\begin{array}{l|c|c}
8 \text { tons } & 2000 \mathrm{lb} & 6000 \mathrm{Btu} \\
\hline \text { Acre-yr } & \text { ton } & 1 \mathrm{~b}
\end{array}
$$

On the other hand, consider an oil reservoir that is ten feet thick, with a porosity of $25 \%$ and $0 i l$ saturation of $65 \%$. The energy density in this case is $53 \times 10^{9}$ BTU/acre.

$$
\begin{aligned}
& 10 \mathrm{ft} \mid \begin{array}{c|c|c|c|c}
43,560 \mathrm{ft}^{2} & 0.25 \mathrm{ft}^{3} \text { void } & 0.65 \mathrm{ft}^{3} \mathrm{oil} & 501 \mathrm{boil} & 15000 \mathrm{BTU} \\
\hline \text { Acre } & \mathrm{ft}^{3} \text { formation } & \mathrm{ft}^{3} \text { void } & \mathrm{ft}^{3} \text { oil } & 1 \mathrm{~b}
\end{array} \\
& 53 \times 10^{9} \frac{\text { BTU }}{\text { Acre }}
\end{aligned}
$$

One location where biomass can be found in large quantities is in a cattle feedlot. Feedlots containing 50,000 to 100,000 cattle are relatively common in some parts of the country, including West Texas. (3). Each cow produces six to eight pounds per day of manure which means that a large quantity of manure is available in one location. This manure is currently used for fertilizer, but the cost of transporting and applying the manure restricts its use as fertilizer to areas near the feedlot.

In 1971, a project was initiated at Texas Tech University to develop methods to convert cattle manure to more valuable products that could be easily transported. The process which has emerged is thermochemical gasification (5). The process is designated the Synthesis Gas From Manure (SGFM) process. Construction of a $1 / 2$ ton per day pilot plant to evaluate the SGFM process began in 1974 with the support of the U.S. Environmental Protection Agency, Pioneer Corporation and the Texas Cattle Feeders 
Association. Operation of the pilot plant began in 1975. On September 1, 1976, the U. S. Energy Research and Development Administration contracted with Texas Tech to develop a data base for partial oxidation and pyrolys is of manure in the SGFM pilot plant that could be used as a basis for a commercial scale plant. This work was part of the Fuels From Biomass program, ERDA and was designated Phase I when the contract was extended on September 1, 1977. Phase II of the program is now in progress to develop a similar data base for wood and wood residue as well as investigation of other agricultural residues (sorghum stalks, corn stalks, etc.).

This paper presents the results of Phase I of the project now funded by the U. S. Department of Energy. A large amount of data is presented with very little explanation. Analysis of the data is in progress. One segment of Phase II will be to develop a kinetic model to correlate the results presented in this paper. A preliminary kinetic model has been presented previously (9) as has a detailed description of the SGFM process (10).

\section{SGFM Process Overview}

A schematic diagram of the pilot-scale processing apparatus is given in Figure 1. Solid feed is fed to the top of the reactor and falls countercurrent to a gas mixture of steam, air, and product gases. Product gas from pyrolysis and partial oxidation exit (with input fluids) out the top of the reactor. The product gas is stripped of entrained solids, tar, and a water/organic mixture using a cyclone, impinger, and heat exchanger respectively. Char is removed from the bottom of the reactor through a centerport opening in the inlet gas distributor. 


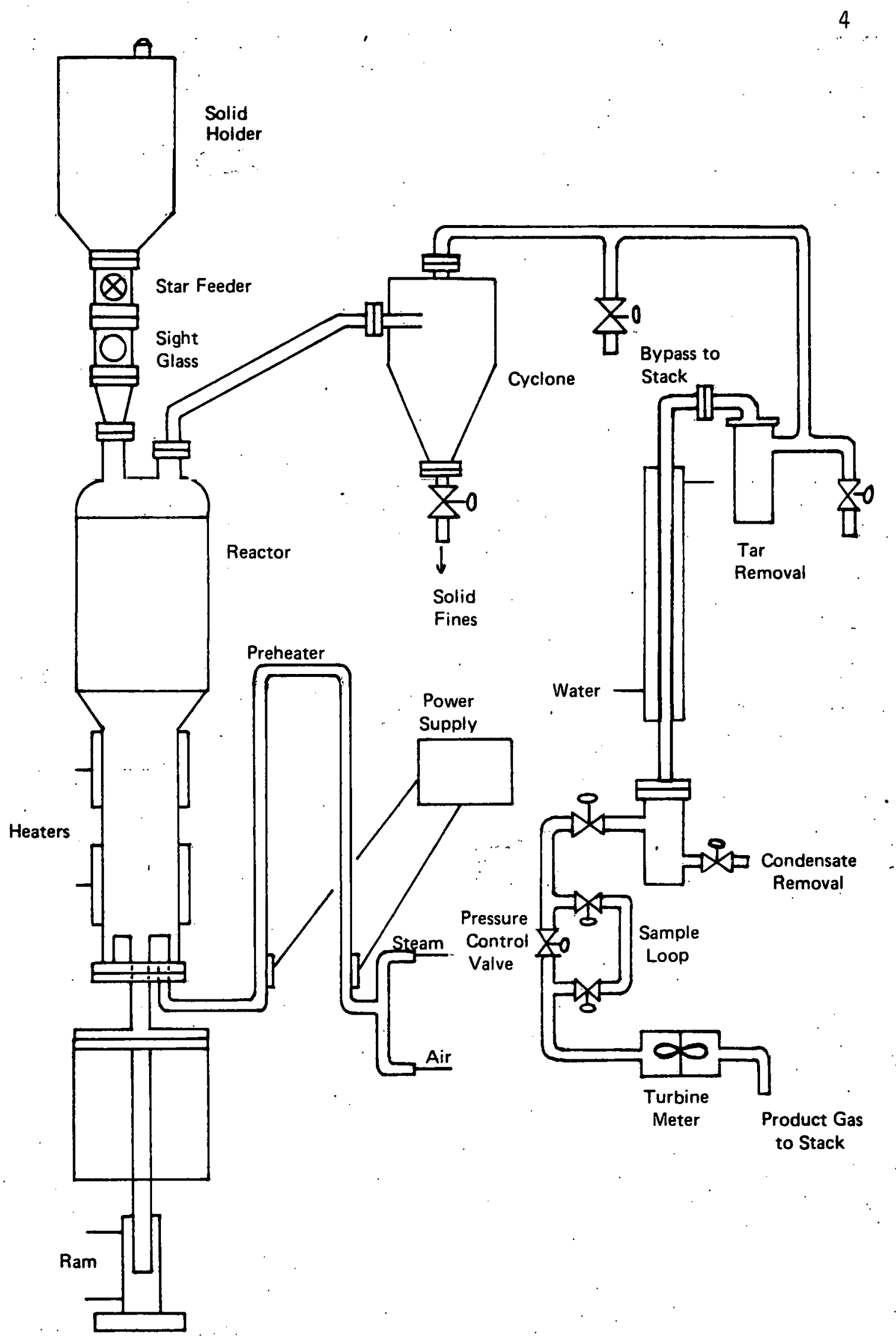

FIGURE 1: FLOWSHEET OF SGFM EXPERIMENTAL UNIT 
A typical temperature profile along the reactor length is shown in. Figure 2. This graph shows the effect of cool solids entering the top of the reactor as well as the effect of combustion or partial oxidation in the lower part. The graph also demonstrates that severe heat losses are currently encountered in the reactor. This heat-loss feature was retained during Phase I until sufficient data were obtained to help explain an unexpected high concentration of hydrocarbon in the product gas.

Operation of the reactor system begins with heat-up to the desired operating temperature. Our results show that the best data (heat balance, mass balance, product composition) are obtained when the heat-up continues to about six (6) hours. At this time, the metal has reached a thermal steady-state. After reaching this thermal steady-state, feed is begun and another steady-state is reached after one to two hours. Only after the second steady-state, are data recorded. Data are generally obtained over a one to three hour period.

\section{Phase I Results and Discussion}

\section{A. Mass Balance Data}

Examples of mass balance data that have been obtained during Phase I are shown in Table I. These results show that mass balances in excess of $90 \%$ have been obtained on a regular basis. This improvement over early balances of $75-85 \%$ has been due, in large part, to extended durations of both the thermal (reactor metal) steady-state and the feed steady-state. These better mass balance data do not show any major shifts in yield(s) over previous results; but, the results can now be used with a greater degree of confidence in making economic estimates. 


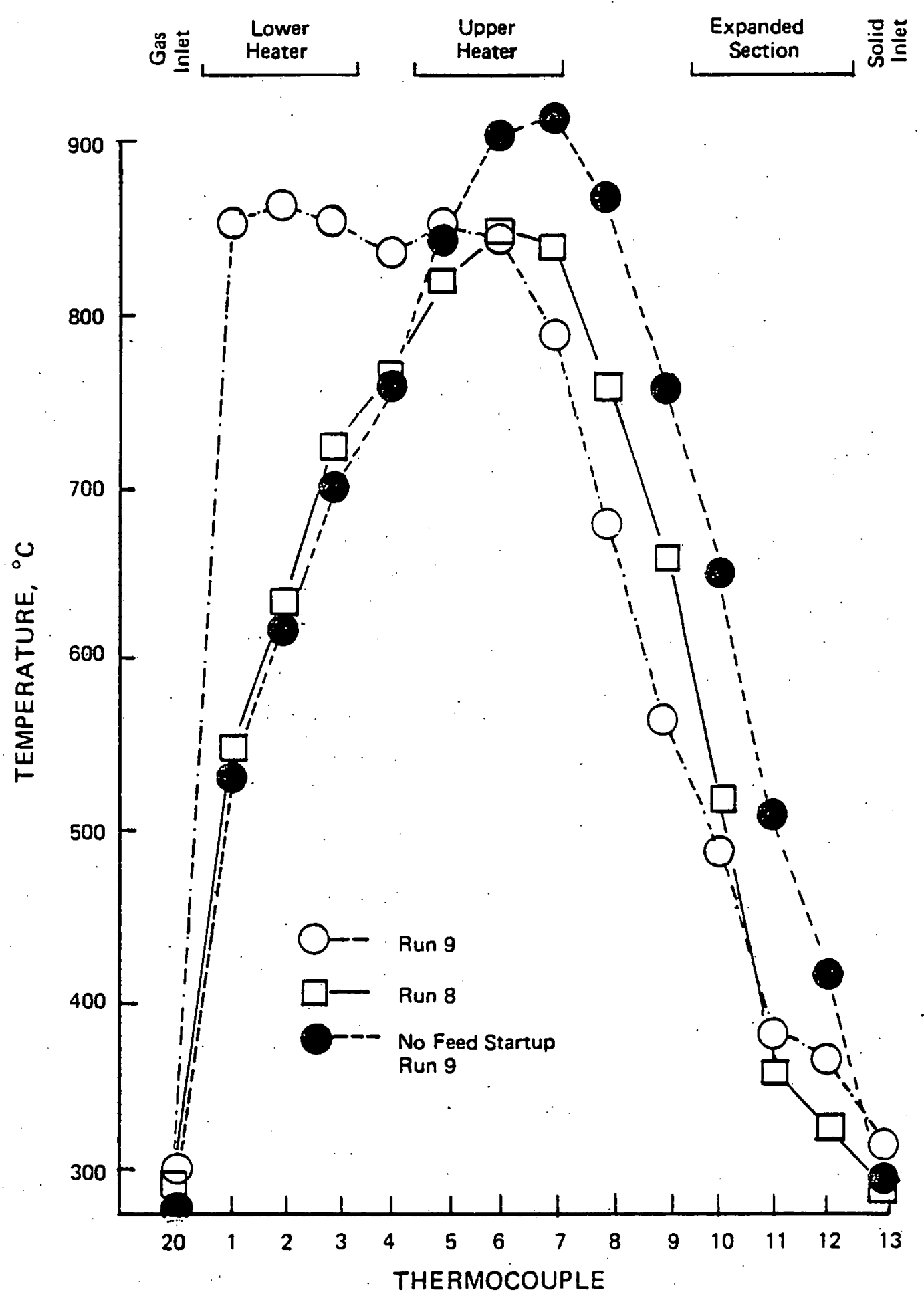

FIGURE 2: EXAMPLES OF REACTOR TEMPERATURE PROFILES 


\section{TABLE I}

\section{EXAMPLE MASS BALANCE DATA}

(All data represent individual experimental measurements; product gas was calculated from experimental gas composition data and measured volumetric flow rate; each run preceded by one hijur of operation with feed.)

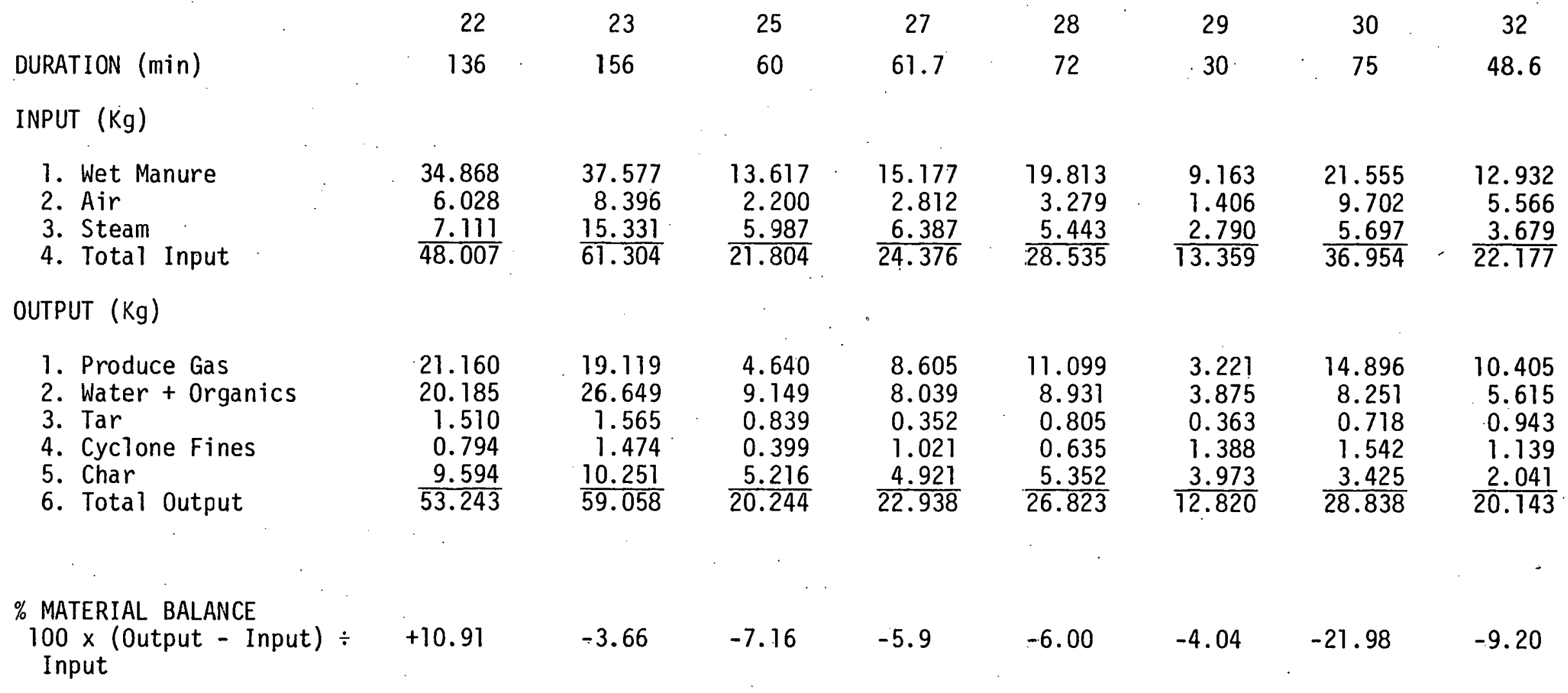


The results still suggest that all of the mass output is not being collected. The discrepancy is estimated to reside in two measurement areas: (1) the product tar is difficult to collect and probably precipitates/condenses with other material on pipe walls; (2) gas composition analysis ignores acetylene and hydrocarbon greater than $\mathrm{C} 2$ 's.

A complete set of carbon balance are not available due to $\mathrm{CHN}-$ instrument problems. The limited data that are available do suggest that Figure 3 for earlier data are still valid.

\section{B. Heat Balance Data}

Heat balance data required additional studies beyond mass balance results because the reactor system heat losses had to be determined independently. The heat losses from the existing system are shown in Figure 4. These data were obtained using one to four electric heaters (no control) with air alone $(\bullet)$ or air plus steam feed $(\boldsymbol{w}$. The total gas throughput was comparable to that observed during actual operation. During a run with manure feed, actual heat losses exceeded $3000 \mathrm{kcal} / \mathrm{hr}$.

Figure 4 shows that these heat loss data are internally consistent because the data can be extrapolated to a zero-zero intercept. These same data were used to calculate a convective heat transfer coefficient after correcting for radiant losses. The average, convective heat transfer coefficient was estimated to be $0.93 \mathrm{cal} / \mathrm{hr} \cdot \mathrm{cm}^{2} \cdot \Delta^{\circ} \mathrm{C} \pm 16 \%$ (approximately $1.9 \mathrm{BTU} / \mathrm{hr} \cdot \mathrm{ft}^{2} \cdot \Delta^{\circ} \mathrm{F}$ ) which is within acceptable engineering limits, considering the non-uniformity of insulation, estimated radiation losses, and conduction losses through connecting piping and superstructure. Hence, the heat loss data of Figure 4 are estimated to be accurate even though precision 


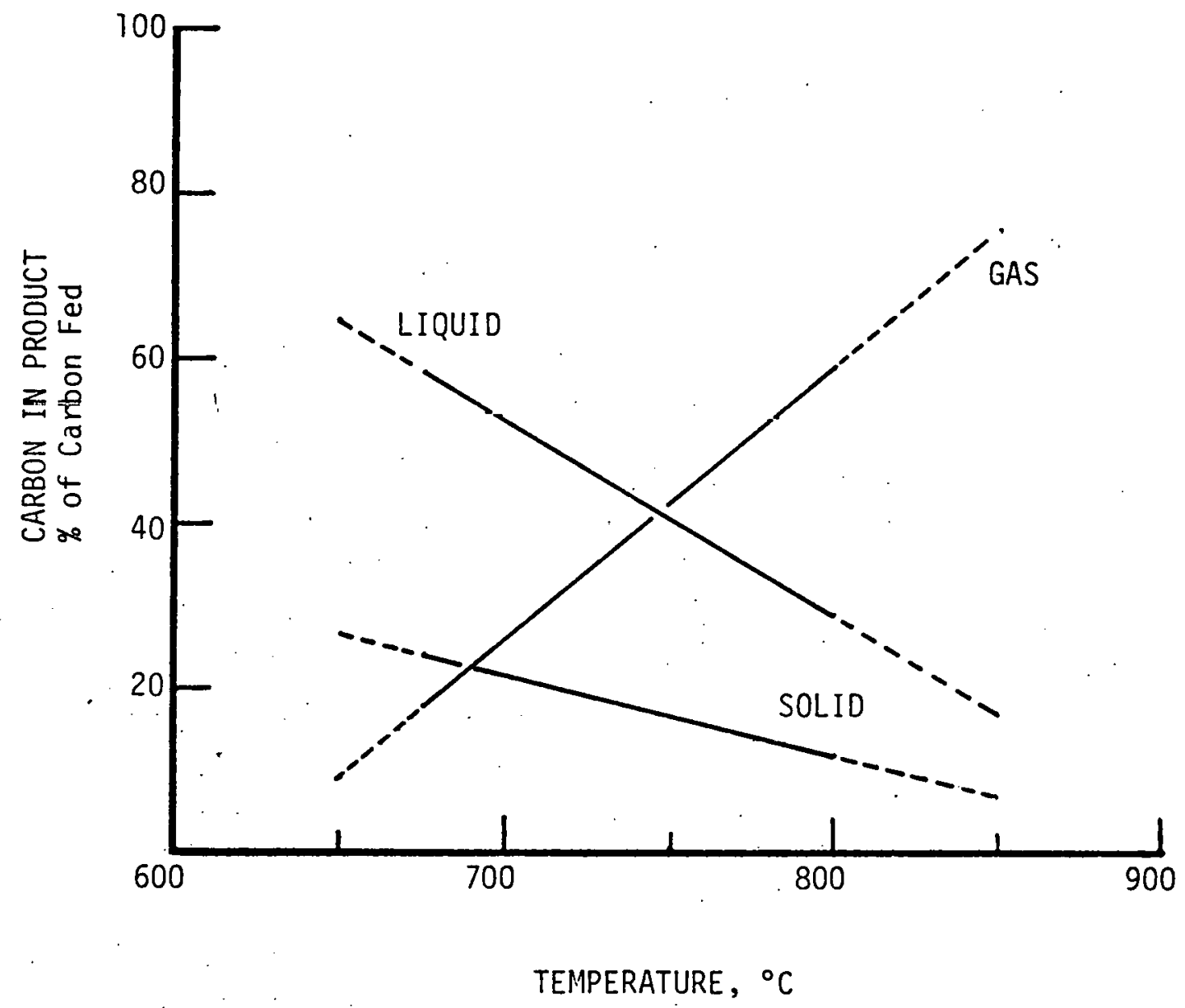

FIGURE 3: DISTRIBUTION OF CARBON IN PRODUCTS.

SOLID LINES INDICATE DATA RANGE. 


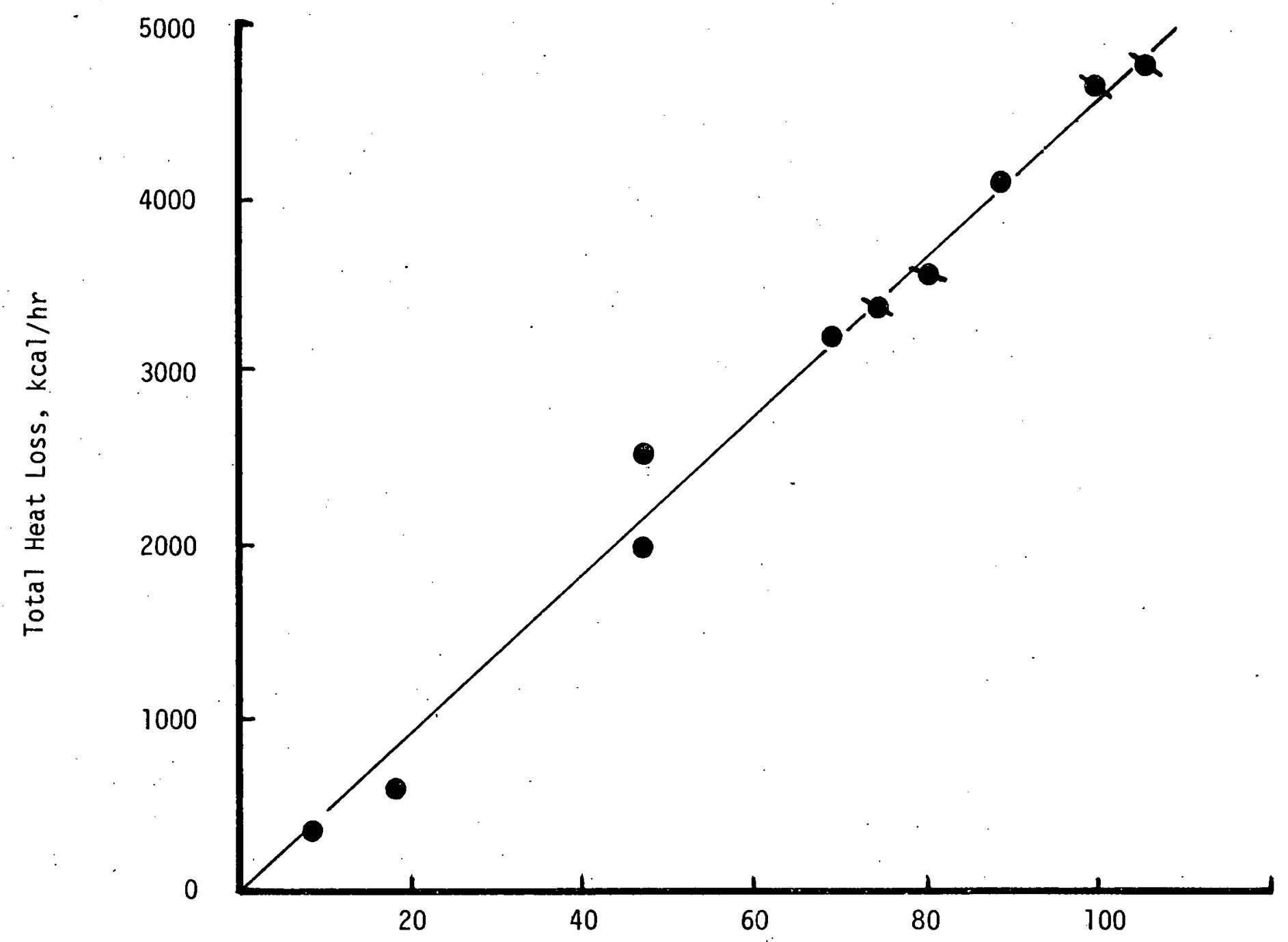

(Average Insulation Temp.) - (Ambient Temp.), ${ }^{\circ} \mathrm{C}$

Figure 4: Experimental Heat Loss Data for SGFM Reactor 
cannot be considered to be any better than $\pm 5 \%( \pm 200 \mathrm{kcal} / \mathrm{hr}$. at $4000 \mathrm{kcal} /$ hr loss rate).

A summary of the heat balance data using cattle feedlot manure as feed are shown in Table II. It should be noted that the data represented here also include the mass balance of Table I. The total $\Delta H r$ (= Input - Output) are shown in Figure 5 as a function of air feed rate.

These results indicate that the overall reaction with manure feed is mildly exothermic with $\Delta H r=-122 \pm 55$ cal per gram of dry, ash-free material converted $(\Delta \mathrm{Hr}=-220 \pm 99 \mathrm{BTU} / 1 \mathrm{~b}$ drỵ, ash-free material converted). An average value of $-\Delta \mathrm{Hr}=94 \mathrm{cal} / \mathrm{gram}$ was obtained if the heat of combustion equivalent to $\mathrm{C}+\mathrm{O}_{2} \longrightarrow \mathrm{CO}_{2}$ was subtracted from each of the runs in Table II. The $\Delta \mathrm{Hr}$ values given here are based on a temperature of $25^{\circ} \mathrm{C}$.

It must be appreciated that the $(-\Delta H r)$ value is considered to be only an order-of-magnitude estimate. The value represents only $5-15 \%$ of the total heat input or output. In other words, the differences between heat input and heat output that were used to calculate the $(-\Delta H r)$ to approach the error limits of the individual values in each run. This limitation is particularly true at the lower reaction rates. A value of approximately $120 \mathrm{cal} /$ gram is thought to be sufficiently close to zero to be consistent with other data reported in the literature.

The heat balance results do show, in general, that the SGFM partial oxidation can be considered to be autothermal if proper and efficient heat exchange can be accomplished between the inlet and exit streams with minimum heat losses. This summation is illustrated in Table III for $80 \%$ exchange between the inlet and outlet streams with $10 \%$ heat losses. The excess heat 
TABLE II

HEAT BALANCE RESULTS

RUN NO.

INPUT (a)

1. Manure, as-received

2. Air

3. Steam

4. Helium

5. Heaters

INPUT TOTAL

OUTPUT(a)

1. Losses (b)

2. Steam

3. Product Gases

4. Char

5. Fines

6. Tar

7. Liquids

8. Helium

OUTPUT TOTAL

$\%$ Loss $=\frac{\text { Loss }}{\text { Input }} 100$

TOTAL $\triangle H r=$ INPUT - OUTPUT

(a) $25^{\circ} \mathrm{C}$ REFERENCE; BTU/HR

(d) $\mathrm{C}+\mathrm{O}_{2} \longrightarrow \mathrm{CO}_{2}$
25

27

28

0
686

17315

0

$\underline{28566}$

46567

0
718
12742

12742

0

27729

41189

19000

21350

10029

1429

350

404

293

2734

55589

66.51

$-9022$

$\begin{array}{r}19500 \\ 16910 \\ 11352 \\ 1331 \\ 201 \\ 766 \\ 1331 \\ 1467 \\ \hline\end{array}$

16750

20100

8670

2018

876

804

$-500$

1531

45180

74.99

$-7888$

70.32

51249

70.13

. .11669

$-11478$

16300
17195

17195
17439

17439
696

418

664

487

1647

54846

68.60

$-16989$

(c) $8.9 \%$ MOISTURE EXCEPT RUN 30 WHICH WAS $21.7 \%$
32

0

1070

12022

0

$\underline{27630}$

40722

18800

17188

22033

496

533

1438

2511

1983

64982

68.04

$-24260$ (b) FROM CALIBRATION DATA 


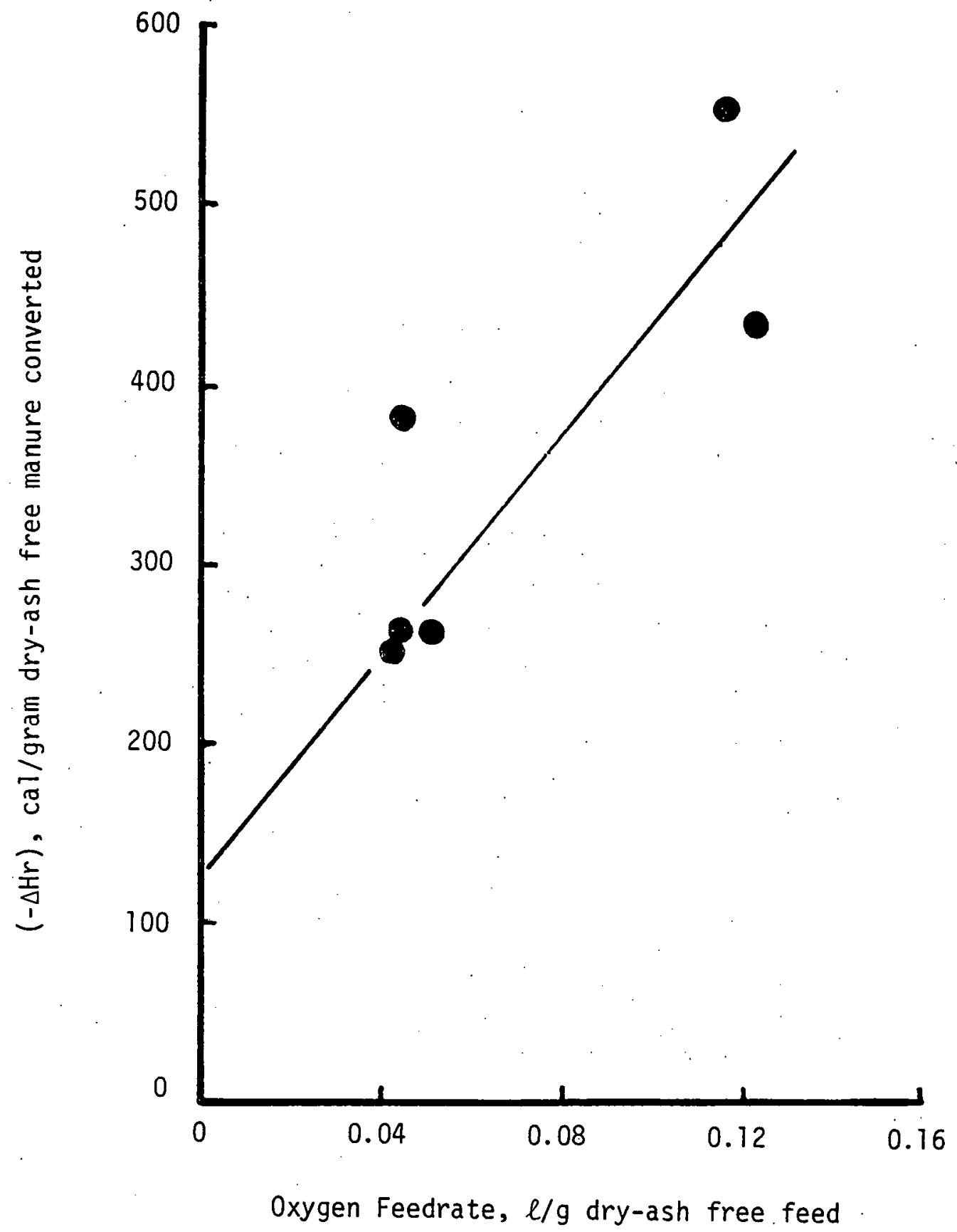

FIGURE 5: ESTIMATE OF HEAT OF REACTION 
TABLE III

EXAMPLE CALCULATIONS SHOWING AUTOTHERMAL CHARACTER OF SGFM TECHNOLOGY

Run 25

Run 32

INPUT (BTU)

Manure (Wet; $10 \% \mathrm{H}_{2} \mathrm{O}$ )

Air

0

0

Steam

508

1070

16380

12022

OUTPUT (BTU)

Steam

20395

17188

Gases

4050

22035

Char + Fines

1463

1029

Tar + Liquids

2605

3949

$10 \%$ Heat Losses of Output

(2851)

(4420)

$80 \%$ Efficiency of Output

(5703)

(8840)

Net Output

19959

30941

Net Output - Input

3071

17849

$(\Delta \mathrm{H})$ Water 0 Conditions

1238 BTU/LB

1238. BTU/LB

Potential Added Water

$2.48 \mathrm{~Tb}$

$14.41 \mathrm{~b}$

Potential Moisture Content

$23 \%$

$57 \%$ 
for the calculations show that moisture content of the feed could be as high as $50 \%$ even with the assumed losses.

These estimates do not mean that external heat. would not be necessary. Instead the results suggest that external heat duty could be kept to a minimum. Hence, overall process thermal efficiency should be comparable to those reported for coal processes, $60-70 \%$.

\section{Solid Feed and Product Data}

It is realized that the above heat and mass balance data can only be put in their proper context when the feed is characterized. Figures 6 and 7 show examples of typical product size distribution and heat content. In Figure 6 , the results show that the overall heat content of the as-received feed decreases with decreasing particle size. However, on a dry, ash-free basis, the results of Figure 7 suggest that the reactive material in the manure feedstock does not change drastically. as a function of particle size, i.e., the heat of combustion is relatively constant. Furthermore, the results also suggest that both "fines" and larger particles exhibit a reasonable degree of reaction, approximately $30 \%$ of the material in the fines converted and up to $90 \%$ of the bulk feed were converted in runs 25 thru 32 . Overall conversion of reactive material ranged from $65 \%$ to $90 \%$, based on ash data for these runs.

Complete results on the $\mathrm{C}, \mathrm{H}, \mathrm{N}, \mathrm{O}, \mathrm{S}$ content of the solid feed and product are not yet available. Current results show, however, that feed material was comparable to that reported earlier: $35-45 \% \mathrm{C}, 5-6 \% \mathrm{H}, 2.5-$ $3.0 \% \mathrm{~N}, 0.5-1.5 \% \mathrm{~S}$, and $24-28 \% 0$ on a dry basis with $15-30 \%$ ash. 


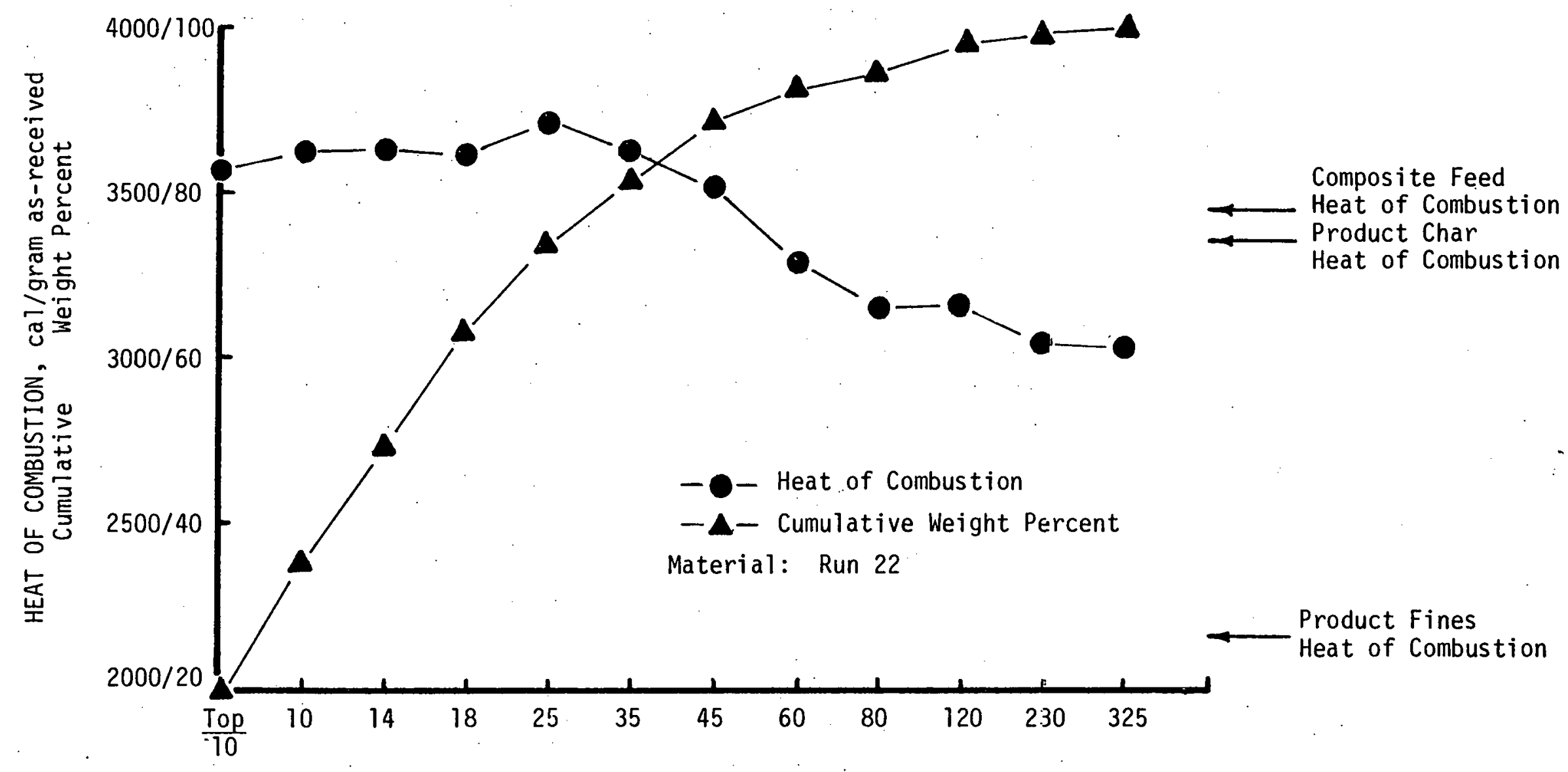

SIZE CLASSIFICATION OF MANURE FEED

U. S. Standard Screen Size

Figure 6: Gross Heat of Combustion Data For Cattle:

Feedlot Manure Feedstock 


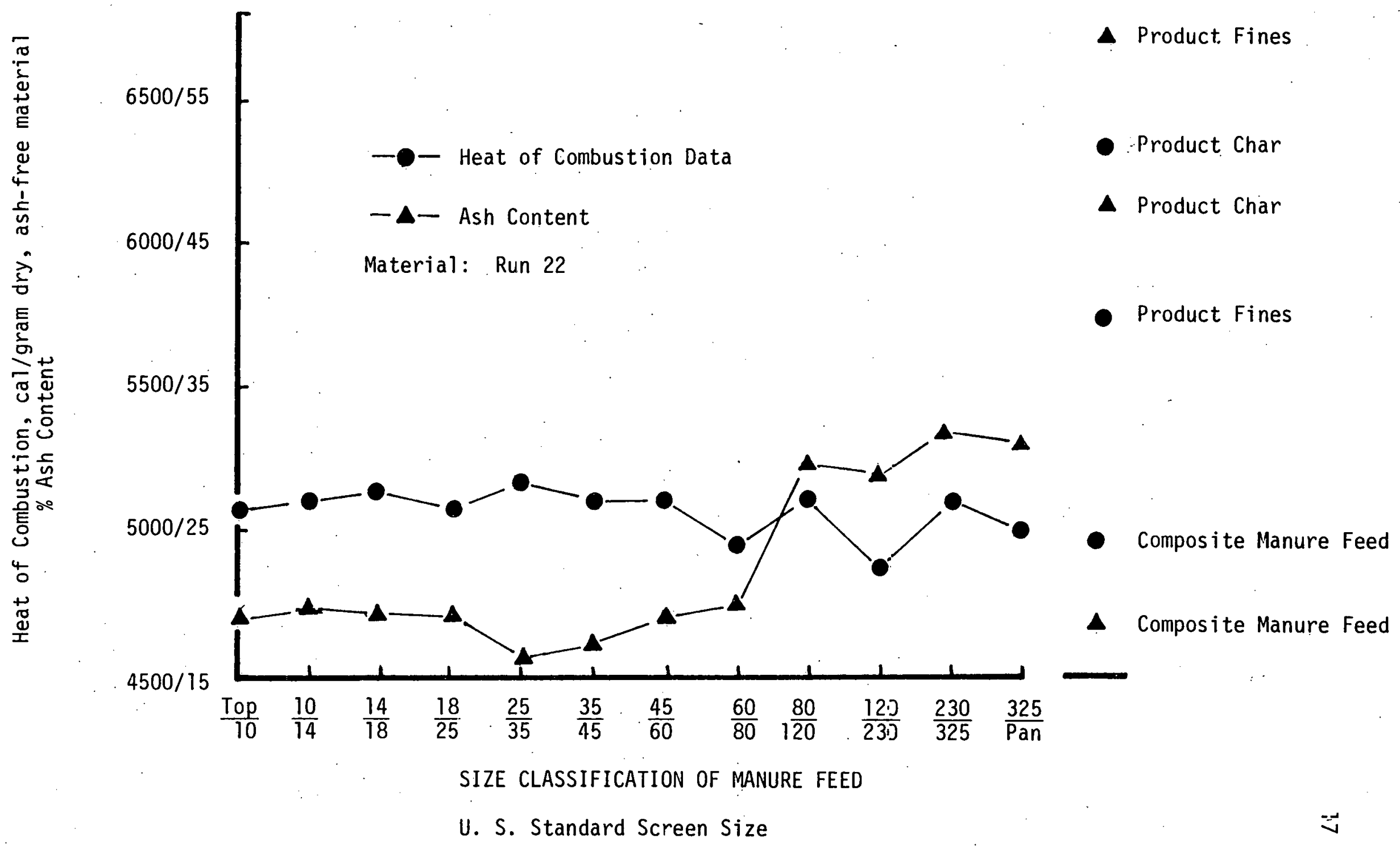

Figure 7: Heat of Combustion Data for Cattle Manure on Dry, Ash-Free Basis 
The same data also illustrate that particle size of the solid does not change much during the course of reaction. There does, however, appear to be a small shift towards smaller particle sizes as illustrated in Table IV. The approximate solid conversion (based on ash content) for each particle size range is also shown in the same table and suggests that particles $>2.0 \mathrm{~mm}$ ( $>0.10$ inch) should be minimized in a full-scale process. Additional data, particularly for Runs 30 and 32 at higher, overall conversion levels, on conversion versus particle size remain to be summarized and will be reported.

Additional data on overall; fractional conversion of solid material is given in Table $V$. These results help demonstrate that a relatively high degree of solid conversion has been achieved during investigations using cattle feedlot manure. The $93 \%$ solid conversion is expected to be approaching the upper limit because the entrainment of fines $(<0.01$ inch $.000 .03 \mathrm{~cm})$ during reaction.

\section{Gas Yield and Composition}

The data base developed on the conversion of cattle feedlot manure in the SGFM reactor is given in Table VI. This table illustrates the range of operating conditions as well as product gas data. An overall interpretation of these data is given later relative to total conversion and synthesis gas generation.

Internal reactor gas compositions were also obtained for four of these runs (19 thru 23). These results were obtained to develop a basic understanding of the partial oxidation-pyrolysis reactions and fluidization characteristics occurring within the reactor and provide data for developing scale-up principles and/or guidelines. 
TABLE IV

COMPARISON OF PARTICLE SIZE DISTRIBUTION

OF FEED AND CHAR

\begin{tabular}{|l|c|c|c|c|c|}
\hline \multicolumn{1}{|c|}{ ITEM } & \multicolumn{5}{|c|}{ Screen Diameter, mm } \\
\hline \multirow{2}{*}{ Wt \% in Feed } & $0-0.7$ & $0.71-1.0$ & $1.01-1.41$ & $1.42-2.0$ & $>2.0$ \\
\cline { 2 - 6 } & 36.8 & 13.4 & 14.0 & 16.2 & 19.6 \\
$\begin{array}{l}\text { Wt \% in Char, } \\
\text { Run 22 }\end{array}$ & 35.5 & 16.8 & 16.4 & 17.1 & 14.3 \\
$\begin{array}{l}\text { Wt \% in Char, } \\
\text { Run 23 }\end{array}$ & 32.9 & 15.5 & 15.4 & 21.5 & 14.9 \\
$\begin{array}{l}\text { Approximate So1id } \\
\text { Conversion } \\
\text { Run 22 } \\
\text { Run 23 }\end{array}$ & 0.70 & 0.65 & 0.59 & 0.54 & 0.37 \\
& 0.70 & 0.66 & 0.59 & - & 0.45 \\
\end{tabular}


TABLE $V$

FRACTIONAL CONVERSION OF REACTIVE MATERIAL IN SOLID FEED

\begin{tabular}{|c|c|c|c|c|c|}
\hline $\begin{array}{c}\text { Run } \\
\text { Number }\end{array}$ & $\begin{array}{c}\% \text { Ash } \\
\text { in } \\
\text { Feed } \\
\end{array}$ & $\begin{array}{c}\% \text { Ash } \\
\text { in } \\
\text { Char } \\
\end{array}$ & $\begin{array}{c}\% \text { Ash } \\
\text { in } \\
\text { Fines } \\
\end{array}$ & $\begin{array}{l}\text { Ib fines } \\
\text { per } \\
1 \mathrm{~b} \text { char }\end{array}$ & $\begin{array}{l}\text { Fractional } \\
\text { Conversion }\end{array}$ \\
\hline & $(\alpha)$ & $\left(x_{c}\right)$ & $\left(x_{f}\right)$ & (a) & (f) \\
\hline 25 & 0.1886 & 0.4590 & 0.6700 & 0.0781 & 0.7424 \\
\hline 27 & 0.2024 & 0.5395 & 0.6715 & 0.2081 & 0.8024 \\
\hline 28 & 0.2144 & 0.4195 & 0.6180 & 0.1167 & 0.6529 \\
\hline 29 & 0.1918 & 0.5870 & 0.6028 & 0.3472 & 0.8358 \\
\hline 30 & 0.1957 & 0.7090 & 0.6735 & 0.4552 & 0.8946 \\
\hline 32 & 0.1876 & 0.8047 & 0.6488 & 0.4745 & 0.9261 \\
\hline
\end{tabular}

Notes: (a) All values on a dry basis

(b) $1-f=\alpha(1-\beta) / \beta(1-d)$

$\beta=\left(a X_{f}+x_{c}\right) /\left(1+a_{1}\right)$ 
TABLE VI

OPERATING CONDITIONS AND PRODUCT GAS DATA

\begin{tabular}{|c|c|c|c|c|c|c|c|}
\hline \multirow{2}{*}{ Operating Conditions } & \multicolumn{7}{|c|}{ Run Number } \\
\hline & 1 & $6 a$ & $6 b$ & 7 & 8 & 9 & 10 \\
\hline Manure Feed Rate, Ib daf/hr(a) & 11.5 & 15.9 & 35.6 & 28.6 & 29.2 & 28.0 & 18.2 \\
\hline Manure Feed Rate, 1b ar/hr & 17.1 & 23.3 & 52.0 & 41.8 & 39.8 & 39.7 & 25.9 \\
\hline Air Feed Rate, SCF/hr & 40.5 & 60.0 & 52.5 & 67.2 & 49.5 & 150 & 27.0 \\
\hline Steam Feed Rate, $\mathrm{lb} / \mathrm{hr}$ & 12 & 10 & 10 & 8 & 6.8 & 6 & 8.2 \\
\hline Average Temperature, ${ }^{\circ} \mathrm{C}$ & 670 & 655 & 600 & 575 & 590 & 630 & 590 \\
\hline \multicolumn{8}{|l|}{ Product Gas Data ${ }^{(b)}$} \\
\hline Total Dry Gas, SCF/lb daf (c) & 19.1 & $(10.7)$ & 9.3 & 6.5 & 7.3 & $(11.5)$ & 5.1 \\
\hline Heat Value (HHV), BTU/SCF & 321 & 328 & 426 & 380 & 396 & 295 & 376 \\
\hline Gas Composition, Vol \% & & & & & & & \\
\hline $\mathrm{H}_{2}$ & 25.2 & 22.2 & 20.0 & 28.2 & 17.4 & 15.1 & 20.9 \\
\hline $\mathrm{N}_{2}$ & 14.6 & 27.8 & 15.7 & 23.2 & 26.7 & 36.8 & 24.2 \\
\hline $\mathrm{CH}_{4}$ & 12.8 & 7.7 & 12.6 & 9.2 & 14.1 & 8.9 & 11.7 \\
\hline $\mathrm{CO}$ & 11.6 & 15.3 & 21.3 & 16.4 & 21.2 & 20.3 & 22.4 \\
\hline $\mathrm{CO}_{2}$ & 30.8 & 20.7 & 22.1 & 15.4 & 14.1 & 14.2 & 14.8 \\
\hline $\mathrm{C}_{2} \mathrm{H}_{4}$ & 4.7 & 6.4 & 8.5 & 4.9 & 5.8 & 4.2 & 5.5 \\
\hline $\mathrm{C}_{2} \mathrm{H}_{6}$ & 0.3 & 0.5 & 0.4 & 2.7 & 0.7 & 0.5 & 0.5 \\
\hline
\end{tabular}

(a) daf = dry, ash-free; ar $=$ as-received

(b) All data are average values from at least two samples. Individual gas samples were analyzed on the gas chromatograph using a.t least two injections:

(c) Values in parentheses are back-calculated values using a nitrogen balance. 
TABLE VI (continued)

\begin{tabular}{|c|c|c|c|c|c|c|c|c|c|c|c|}
\hline \multirow[t]{2}{*}{ Operating Conditions } & \multicolumn{11}{|c|}{ Run Number } \\
\hline & 19 & 20 & 21 & 22 & 23 & 25 & 27 & 28 & 29 & 30 & 32 \\
\hline Manure Feed Rate, Ib daf/hr (a) & & & 24.54 & 23.57 & 23.31 & 22.18 & 23.65 & 26.05 & 29.75 & 23.94 & 26.03 \\
\hline Manure Feed Rate, Ib ar/hr & 33.3 & 32.9 & 33.4 & 33.9 & 31.86 & 30.0 & 32.56 & 36.4 & 40.4 & 38.02 & 35.17 \\
\hline Air Feed Rate, SCF/hr & 66 & 63.6 & 70.2 & 72.6 & 74 & 60.2 & 74.7 & 77.9 & 26.6 & 212.0 & 188 \\
\hline Steam Feed Rate, $1 \mathrm{~b} / \mathrm{hr}$ & 10 & 14 & 10.6 & 12.5 & 14 & 13.21 & 14.1 & 12 & 12.3 & 10.0 & 10 \\
\hline Average Temperature, ${ }^{\circ} \mathrm{C}$ & & & 596 & 629 & 577 & 517 & 619 & 629 & 533 & 573 & 636 \\
\hline \multicolumn{12}{|l|}{ Product Gas Data ${ }^{(b)}$} \\
\hline Total Dry Gas, SCF/lb daf ${ }^{(c)}$ & & & 10.2 & 12.60 & 10.25 & 6.20 & 12.35 & 13.36 & 8.10 & 19.67 & 19.66 \\
\hline Heat Value (HHV), BTU/SCF & 321.8 & 325.3 & 351.1 & 335.8 & 338.9 & 270.9 & 309.6 & 300.7 & 326.9 & 265.31 & 268.6 \\
\hline \multicolumn{12}{|l|}{ Gas Composition, vol \% } \\
\hline $\mathrm{H}_{2}$ & 24.75 & 26.44 & 21.04 & 23.78 & 17.66 & 3.68 & 21.87 & 24.60 & 30.0 & 30.93 & 32.92 \\
\hline $\mathrm{N}_{2}$ & 21.59 & 20.55 & 17.78 & 18.84 & 23.16 & 22.65 & 22.35 & 24.00 & 16.10 & 23.00 & 21.23 \\
\hline $\mathrm{CH}_{4}$ & 9.11 & 9.04 & 9.34 & 9.82 & 10.69 & 8.15 & 8.27 & 8.76 & 9.20 & 6.27 & 6.19 \\
\hline $\mathrm{CO}$ & 11.69 & 13.07 & 13.23 & 14.56 & 13.56 & 10.03 & 13.84 & 14.57 & 13.0 & 11.63 & 11.05 \\
\hline $\mathrm{CO}_{2}$ & 27.02 & 25.41 & 30.72 & 27.14 & 28.00 & 39.56 & 27.87 & 23.79 & 27.0 & 25.13 & 25.57 \\
\hline $\mathrm{C}_{2} \mathrm{H}_{4}$ & 5.20 & 4.86 & 6.98 & 5.25 & 6.13 & 4.37 & 5.0 & 3.61 & 3.34 & 2.13 & 2.26 \\
\hline $\mathrm{C}_{2} \mathrm{H}_{6}$ & 0.65 & 0.63 & 0.88 & 0.611 & 0.79 & 1.56 & 0.8 & 0.67 & 1.36 & 0.91 & 0.78 \\
\hline
\end{tabular}

\footnotetext{
(a) daf = dry, ash-free; ar = as-received

(b) All data are average values from at least two samples. Individual gas samples were analyzed on the gas chromatograph using at least two injections.
}

(c) Values in parentheses are back-calculated values using a nitrogen balance. 
A qualitative summary of the internal compositions is given in

Figure 8. An interpretation of these data have indicated that:

- Approximately $50-75 \%$ of the pyrolysis reactions occur in the lower one-third of the reactor. This was somewhat unexpected because previous "projections" led us to conclude that most of the pyrolysis would occur in the upper one-half. Heat transfer to the larger particles may explain part of this observation. The results suggest that it may be possible to reduce the required reactor volume using somewhat smaller feed particle size and/or providing a better match of temperature profiles.

- Liquid (tar) generation was greatest in the middle of the reactor volume (region of higher temperatures). However, little liquid tar was observed in the very top and bottom of the reactor. These results indicate, along with the individual composition data, that tars should be injected into the middle of the reactor.

- Solid density was highest in the lower part of the reactor. This was an expected result. This observation and the above on. liquid formation were qualitatively established by the amount collected in the sample probes.

- Data analysis showed that, at the existing concentration, as much as $40 \%$ of the ethylene could be decomposing within the reactor. This value is high, but would be much higher if steam were not present. The presence of steam as a diluent 

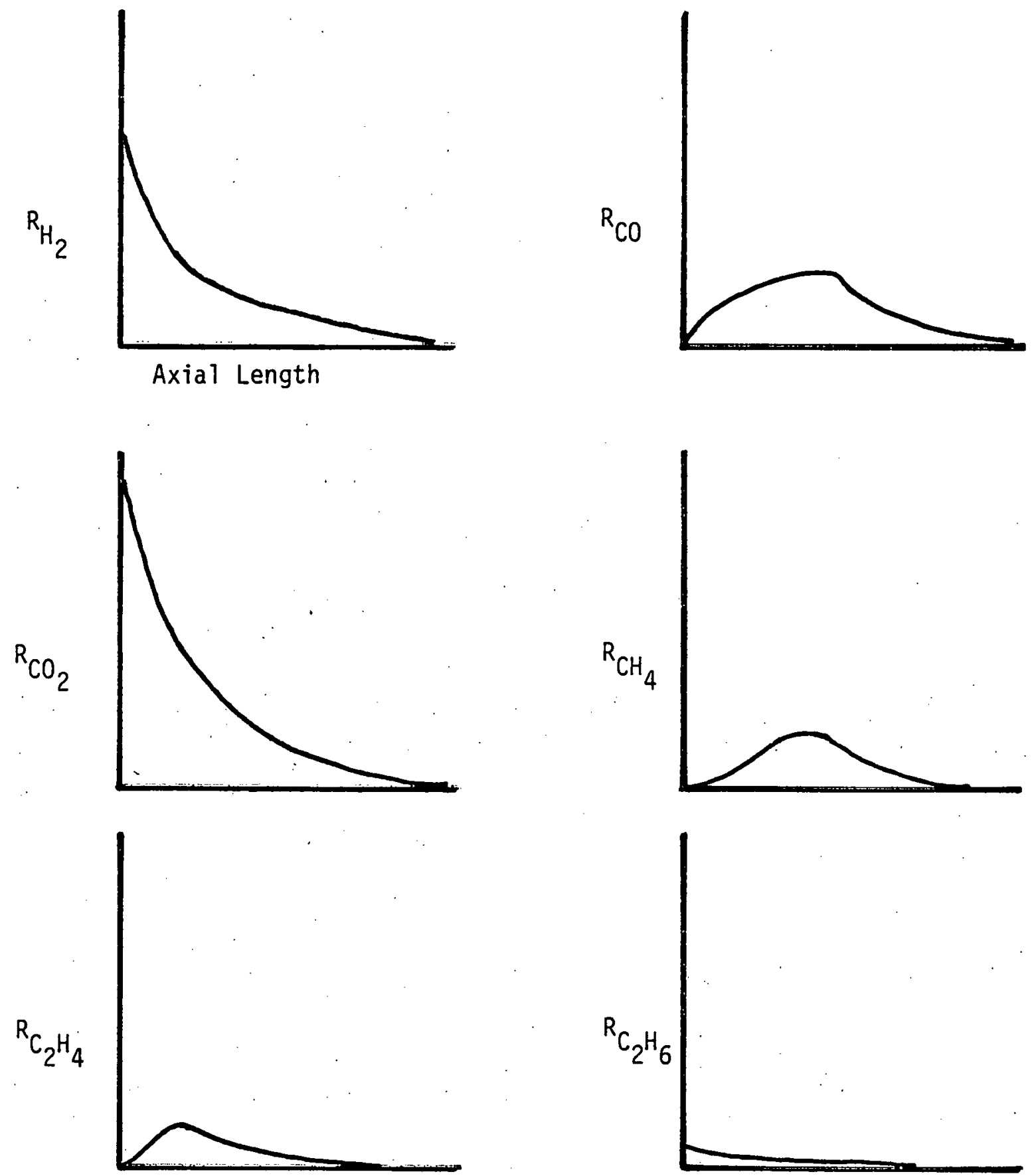

Figure 8: Internal Net Rates of Production 
reduces the rate of decomposition by a factor of 3.5 based on concentration alone and also reduces the residence time at temperature by a factor of 2 . Knowledge of the decomposition of ethylene and similar hydrocarbons is important because these components, even in dilute concentrations, are important, e.g.,

HHV ethylene/HHV Hydrogen $=4.94$.

HHV ethylene/HHV Methane $=1.58$

Or, $5 \%$ ethylene is equivalent to $24.7 \%$ hydrogen or $7.91 \%$ methane in terms of overall heat content of the gas. One goal of thermochemical conversion should, accordingly, be to minimize the decomposition of these hydrocarbons.

- Gas velocity increased by a factor of approximately 2 in the lower part of the reactor $(22 \mathrm{~cm} / \mathrm{sec}$ to $42 \mathrm{~cm} / \mathrm{sec}$ ) and then decreased about $50 \%$ in the upper portion of the reactor. Gas phase residence time in the reactor was estimated to be 7.6 seconds. These results were developed at the conditions of run 3, but would apply to the others in this series (19-23). Gas velocity changes would be more dramatic at higher conversion levels, such as runs 30 and 32 . Gas velocity changes in the absence of steam are indicated by the nitrogen concentration profile in Figure 9. The higher velocities help minimize decomposition of valuable hydrocarbons as discussed above.

The overall results of these internal composition data are still under review because they provide a firm contribution to the understanding 


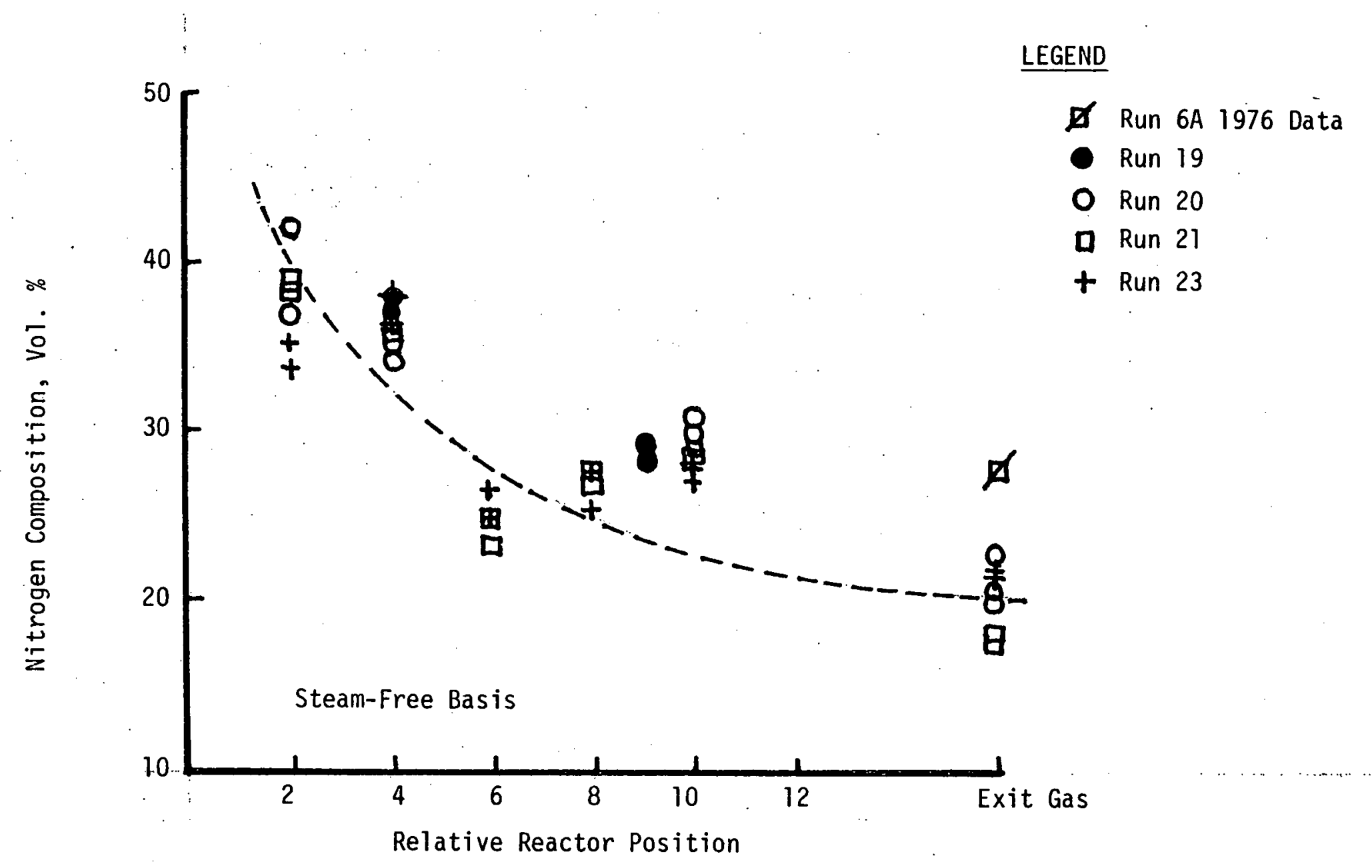

Figure 9:: Nitrogen Concentration Along Axial Reactor Length 
of the reactions and events that are occurring. These data and others will be used to help develop a reactor design model in Phase II.

\section{E. Conversion Efficiency}

The heating value of the produced gas as a function of conversion is shown in Figure 10. The conversion shown is an indication of thermal efficiency and is given as a ratio of the total heat content of gas produced to the heat content of the dry, ash-free feed, based on higher heating value. The early data (Runs $1,6 b, 7,8,10$ ) are not as reliable as the later values due to poor material balances. Figure 11 shows the same data if the $\mathrm{CO}_{2}$ is removed from the gas. With $\mathrm{CO}_{2}$ removal, the gas produced has a HHV that is consistently greater than 300 BTU/SCF.

\section{Conclusions}

Results of the pilot plant tests on cattle manure demonstrate the technical feasibility of the SGFM process. A subcontract has been awarded to the Bechtel Corporation to perform a preliminary process design and economic evaluation of the SGFM process to produce an ammonia synthesis gas or an ammonia synthesis gas plus ethylene from 1000 tons per day of oven-dry cattle feedlot manure. This study will be completed by September 1, 1978 and should provide a good assessment of the economic viability of thermochemical conversion processes.

\section{Acknowledgements}

The authors wish to thank the U. S. Department of Energy (Contract No. EY-76-S-04-3779), the Pioneer Corporation and the Texas Cattle Feeders Association for supporting this project. 


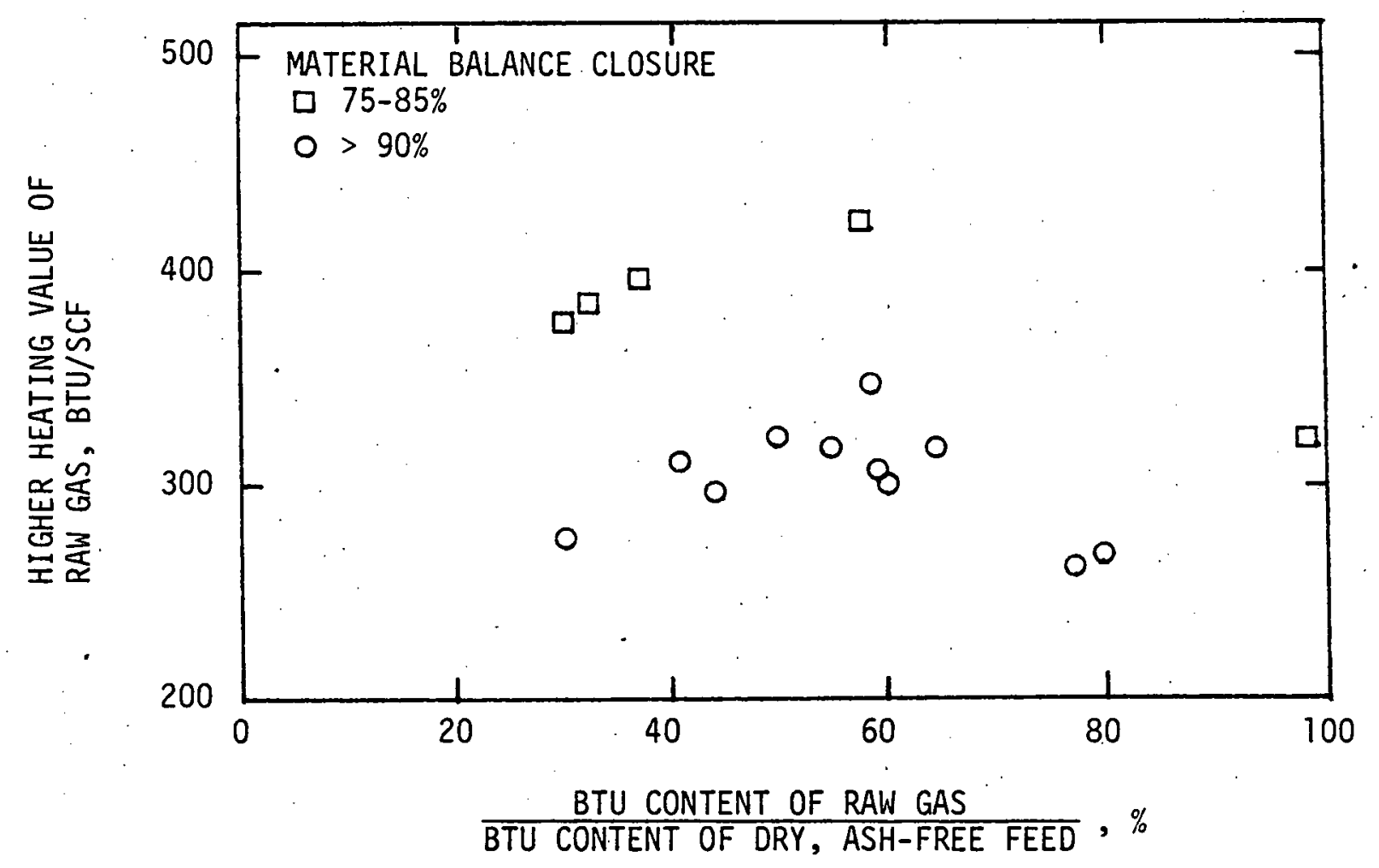

Figure 10: Heating Value of Raw Gas As A Function of Conversion 


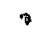



Figure 11: Heating Value of $\mathrm{CO}_{2}-$ Free Gas as a Function of Conversion 


\section{LITERATURE CITED}

1. Jewe11, W. J., Ed., "Energy, Agriculture and Waste Management," Ann Arbor Science, Ann Arbor, 1975.

2. Halligan, J. E., Huffman, W. J., "Potential for Solid Waste as an Energy Source in Texas," Project N/T-10, The State of Texas Governor's Energy Advisory Counci i, 1974.

3. Heichel, G. H., "Agricultural Production and Energy Resources," Amer. Scientist, 64, 64-72 (1976).

4. "National Cattle Feedlot, Meat Packer and Grain Dealers Directory," Tara Publishing Co., Lubbock, 1974.

5. Halligan, J. E., Sweazy, R. M., "Thermochemical Evaluation of Animal Waste Conversion Processes," 72nd National Meeting, AIChE, St. Louis, May 21-24, 1972.

6. Parker, H. W., Whetstone, G. A., "Fuels and Petrochemicals from Agricultural Wastes," 76th National Meeting, AIChE, Tulsa, March 10-13, 1974.

7. Halligan, J. E., Herzog, K. L., Parker, H. W., "Synthes is Gas from Bovine Wastes," Ind. Eng. Chem., Proc. Des. Dev., 14(1), 64-69 (1975).

8. Huffman, W. J., Peterson, R. L., Halligan, J. E., "Ammonia Synthes is Gas Generation from Cattle Feedlot Manure," Centennial ACS Meeting, Div. Fertil. Soil Chem., April 6-7, 1976.

9. Huffman, W. J., Lin, C., Beck, S. R., Halligan, J. E., "Kinetic Analys is of Manure Pyrolyzers," Technical Seminar: Thermochemical Conversion of Biomass Residues, Golden, Co., November 30-December 1, 1977.

10. Peterson, R. L., "A Pilot Plant Study of Synthes is Intermediates from Feedlot Wastes," Masters Thesis, Texas Tech University, Lubbock, 1975. 
